\title{
Terreur, roes en ordes: Die monnik as blywende simbool van erns in die
} filosofie

\author{
Johann Beukes (Weltevredenpark) \\ Navorsingsassosiaat: Fakulteit Teologie \\ Universiteit van Pretoria
}

\begin{abstract}
Terror, frenzy and orders: The monk as persistent symbol of ardour in philosophy

It is argued that postmodern epistemology, in its 21st century guise, is exhausted, with little to offer post-Baudrillard. In thematic conjunction with the critiques of Fredric Jameson, Christopher Norris and Jürgen Habermas, the author depicts 21st century postmodernism as a "frenzied party", where philosophy's historical and characteristic ardour for truth and analysis has been dissolved in favour of a mockery of some of the most profound ideas of Western civilization, such as truth, beauty and justice. The logical consequences of this frenzied epistemology are described as socially devastating, especially within the context of systematic terror, which is described as the predominant social marker of the first years of the 21st century. The author, in reaction both to terror and "epistemological frenzy", attempts to rehabilitate philosophical ardour and a zeal for truth by linking up with the historical persona of "the monk", arguing that our times demand a more studied, retracted and meditative approach to philosophy. Our dreadful times demand a new ardour and sobriety from philosophers.
\end{abstract}

\section{DIE HEENGAAN VAN ERNS EN DIE NUWE TERREUR}

Die postmoderne diskoers bevind sigself in 'n fase van epistemologiese uitbranding. Hierdie is 'n provokatiewe openingstelling. Sommige sou kon meen onnodig

\footnotetext{
*Voordrag gelewer by die jaarlikse Filosofie-Teologie Simposium van die Raad vir Apostolaat van die Nederduitsch Hervormde Kerk van Afrika, gehou op 19 Augustus 2004. Dr Johann Beukes (DLitt et Phil, PhD) is as navorsingsassosiaat betrokke by prof dr Andries $G$ van Aarde se navorsingsprojek, "Bybelse Teologie en Hernemeutiek", Fakulteit Teologie, Universiteit van Pretoria. Die skrywer versoek sy leser om geduld te beoefen met die soort polemiese vryhede wat met 'n voordrag geassosieer kan word wat hy in hierdie teks, synde 'n verbatim kopie van 'n voordrag, veroorloof.
} 
provokatief, selfs geaffekteerd, bloot retories of dalk teatraal. Tog is ek geprovokeer om dié provokatiewe openingstelling te maak: Die agente van my provokasie is filosowe in 'n roekelose en uiteindelik fatale variant van die sogenaamde "postmoderne epistemologie". Hierdie eietydse denkers het aanvanklik kultuurkrities vertrek geneem vanuit Lyotard se latere tekste ( $\mathrm{vgl}$ Beukes 2002:997ev), maar het algaande afstand geneem van die genuanseerde, gereserveerde, bykans futuristiese kultuurkritiek van Lyotard en daarop in veel radikaler terme voortborduur. Hierdie denkers is nie bloot nóg karnavalgangers by die modernkritiese fees van die afgelope dekades nie. Nee, hulle het hulle eie fees begin, 'n party wat herinner aan 'n klassieke Rauschfest, waar begrippe soos waarheid, orde, skoonheid en geregtigheid, asook 'n grondige analise en kritiek van hierdie begrippe, weinig aanspraak meer geniet. Ek het hier in besonder in gedagte die wydgelese Jean Baudrillard en die ontstellende stemme van 'n nuwe geslag denkers soos Paul Virilio en, hoewel in 'n mindere mate, Slavoj Zizek.

Die karnaval van die postmoderne het onder leiding van hierdie denkers en hulle tematiese medegangers sedert die vroeë 1990's in 'n roesparty ontaard, waar - so eie aan die dinamika van roesgesellighede innuendo, of los praatjies, prioriteit bo grondige kritiek en analise geniet. Gelukkig is dit so dat dieselfde dionisiese energie wat roespartye oproep, dit normaalweg ook weer ten gronde rig. Daar is boonop altyd terminerende kodes aanwesig by 'n roesparty, tekens dat dit tyd geword het om huis toe te keer en te gaan herstel: lemand wat 'n duur kristalglas laat val, ' $n$ vaas in die foyer omstamp of dalk met klere en al in die swembad te lande kom. Dan besef almal buiten die ergste vergiftigdes: Genoeg is vir eers genoeg, 'n respyt van roes dan onafwendbaar.

Ook die stemming van die roesparty van die 21 e eeuse variant van die postmoderne epistemologie, verraai die naderende einde van hierdie party: Wanneer mense satiries, sardonies en speels omgaan met epistemologieë van terreur, is dit tyd om huis toe te gaan, om terug te trek. Wanneer paradokse, selfkontradiksies en 'n estetisering, selfs sublimering, van brutaliteit metodologiese status in die filosofie verkry, is dit tyd om te gaan herdink en te gaan herstel. Wanneer met 'n beduidende mate van Schadenfreude gestel word dat niks meer met erns bejeën kan word nie selfs nie die tragiese dood van duisende onskuldige mense op 11 September 2001, of in Madrid op 11 Maart $2004^{1}$ nie; selfs nie die geartikuleerde stemme

\footnotetext{
${ }^{1}$ Daar was op Donderdag 7 Julie 2005 'n terreuraanval in Londen op 3 moltreine en 'n bus, waarin uiteindelik 56 mense, ingeslote 4 selfmoordbombardiers, omgekom het. Die bomaanvalle op 7 Julie is opgevolg met twee mislukte bomaanvalle op 21 Julie en 25 Julie in Londen. Vir 'n goeie tydlyn en omvattende oorsig van die aanvalle op Londen in Julie 2005, kyk http://newswww.bbc.net.uk/1/hi/uk/4694069.stm
} 
van verset teen terreur as die reeds gevestigde sosiale matriks van die eerste jare van die 21e eeu nie, het dit noodsaaklik geword om die kenmerkende filosofiese begrip erns te herondersoek. Wanneer, aan die ander kant, ook niks meer met erns bejeën kan word met verwysing na die Amerikaanse inval in Irak nie, nie inligting - of was dit gerugte? - oor wapens van massavernietiging nie, nie die dood van 'n Irakese burgerlike of 'n Amerikaanse soldaat nie, nie die integriteit van oorlogsgevangenes na beide kante toe nie, dan het dit tyd geword vir haltroep. Die leedvermaak en gebrek aan filosofiese erns ten opsigte van die steeds verhewe, grootse begrip "geregtigheid", noodsaak 'n herondersoek.

Met ander woorde: Die oorwoekerde aanspraak dat niks meer met erns bejeën kan word nie, kan nie in ons tyd met erns geneem word voordat die begrip erns nie eers weer grondig ondersoek is nie. Hierdie artikel verteenwoordig so ' $n$ poging tot ' $n$ herondersoek, dalk selfs ' $n$ poging tot ' $n$ aanvanklike en voorlopige rehabilitering, van die begrip "erns" in die filosofie. Saam met die Heideggeriaan Monika Killian (1998) wil ek hier, gegewe die eietydse internasionale konteks van akute sosiale terreur, die vraag na die "moraliteit" van hierdie spel in die filosofie met die filosofie en die diepste waardes van die Westerse filosofie, naamlik waarheid, geregtigheid en skoonheid, vra.

Jean Baudrillard verteenwoordig 'n kenmerkende stemming onder ' $n$ beduidende aantal eietydse filosowe, naamlik dat dit geheel en al nie meer moontlik is om enige aanspraak op feite, skoonheid, geregtigheid en uiteindelik die waarheid self, te maak nie. Natuurlik is hierdie stemming nie onbekend nie: Minstens sedert Nietzsche is "feite" en "interpretasies" gelykgestel, die een ondenkbaar sonder die ander. Mettergaande het ook waarheid, skoonheid en geregtigheid "estetiese interpretasies" geword, oop ruimtes van die taal, of, sou Baudrillard se beroemdste tematiese voorganger Jean-François Lyotard (vgl Beukes 2002:1009) sê: Dissonante ruimtes van 'n figurale energie.

Sogenaamde "post-strukturalistiese" denkers, soos Michel Foucault en Jacques Derrida, het die wyse waarop tot sosiale strukture, tot die sosiale werklikheid, tot taal, tot kennis, tot die liggaam, tot die wetenskap, tot historisiteit, tot die religie en allerbelangrik, tot die struktuur van die filosofie self genader word, inderdaad onherroeplik verander. Die nalatenskappe van Franse denkers soos Foucault en Derrida het 'n onomkeerbare effek op hierdie benaderings tot strukture en fasette van die sosiale werklikheid. Ek wil daardie post-strukturalistiese nalatenskappe en die geldigheid daarvan ook glad nie hier in dispuut bring nie. Dit is nié waaroor dit hier gaan nie. Ek voel 
my juis tuis in die modernkritiese tradisie. Maar daar was ook 'n ander tradisie wat parallel ontwikkel het, of tot 'n mate eerder ná die opkoms en vestiging van die nou bekende kritiese motiewe van veral Foucault en Derrida: Nie soseer die post-strukturalistiese tradisie nie, maar die kritiese wending op die post-strukturalisme, die tradisie sedert Lyotard self, of, die post-Lyotardiaanse tradisie in die filosofie - dít wat in die lawaaierige geselskappe van die intellektuele mark deesdae so maklik "postmodern" genoem word" ${ }^{2}$ (vgl Beukes 2002:996 ev).

"Postmoderniteit" is die stempel wat Lyotard in 1979 op die hierdie wending in die kontemporêre filosofie, vanaf post-strukturalisme na postmoderniteit, sou plaas, met die publikasie van The postmodern condition (vertaling 1984), 'n boek waarvan die inhoud nou vir die leser reeds oorbekend moet wees: In kort kom dit daarop neer dat die drie meester- of metaverhale van die moderne tyd, te wete 1) die Verligting (met al die emansipatoriese potensiaal daarvan) se aanspraak op vooruitgang, 2) die teleologie van die Idealisme en 3 ) die historisme van die moderne hermeneutiek uitgeput geraak het. Dit is nie soseer die inhoud en aansprake van hierdie metaverhale wat uitgeput geraak het nie, maar volgens Lyotard veral die feit dat die konteks waarbinne hierdie metaverhale eietyds ontvang en ervaar word, radikaal verander het. Hierdie konteks het te make met die ontmaskering van universele aansprake en die gelyktydige konfrontasie met diversiteit in die leefwêreld self. In sosiale gedaante het hierdie radikaal veranderde konteks volgens Lyotard (1984:xxiv) te make met 'n post-

\footnotetext{
${ }^{2}$ Die Franse filosofie gedurende die sestigerjare kan terugskouend in twee duidelike fases onderskei word. In die eerste, strukturalisties-gedrewe fase, word reeds ingrypend-nuwe temas die tradisionele vraagarena van die filosofie binnegebring. Hiervan was 1) die kritiese bevraging van objektiwiteit, 2) die desentrering van die handelende subjek en 3) 'n selfkritiese of selfrefleksiewe poging om aan die tradisionele kennisaansprake van die filosofie te ontkom, die prominentste temas. Die bekendstelling van hierdie temas het egter steeds binne die veelouer raamwerk van die Franse positivisme plaasgevind. In die tweede fase, wat óf beskou kan word as die aanvangsfase van post-strukturalisme óf as die laaste fase van strukturalisme (of dan, laat-strukturalisme), word die vernaamste aanspraak van die positivisme - die positiewe kenbaarheid van die werklikheid deur die objektivering en verwetenskapliking van die werklikheid - juis radikaal heraangespreek. Die kritiese heraanspreke van die positivistiese agtergronde van die strukturalisme het tot ' $n$ verdieping in die verkenning van bogenoemde drie temas gelei, wat uiteindelik die "postmoderne toestand" filosofies sou grondves in die latere werk van Lyotard in besonder. Ek is nie bewus daarvan dat Derrida of Foucault enigsins opgewondenheid getoon het met betrekking tot die begrip "postmodern" of voorkeur sou verleen aan die begrip nie: So ook geen ander noemenswaardige Europese denker voor Lyotard nie. Die post-strukturaliste het bykans dadelik hoogs oorspronklike, idiosinkratiese weë ingeslaan, Foucault byvoorbeeld, met wat hy sou benoem as ' $n$ kennisargeologie, of Derrida, met wat genoem sou kon word die kritiese en spanningsvolle ruimte van différance. Ek wil hiermee eintlik sê dat die begrip "postmodern" vir my 'n verleentheidswekkende begrip geword het, omdat dit vandag so buitengewoon ongenuanseerd, soms selfs heeltemal onvanpas, gebruik word. Ek vind "postmoderniteit" trouens toenemend 'n ondiensbare begrip en verkies deesdae 'n meer neutrale en minder oorwerkte begrip, soos "modernkrities".
} 
industriële, gerekenariseerde, beeldgemedieerde samelewing waar die opvatting van kultuur, tyd, plek, ruimte en die toekoms radikaal verander het. Nie meer feite aangaande die kultuur, die eie plek, die geskiedenis óf die toekoms kan aangebied word nie, maar slegs ad hoc vertellinge daaromtrent, flitsende beelde, fragmente en enkelverhale. Slegs die metaverhale kon ongehinderd, ongemedieerd bestaan en aansprake rig. Die mediërende invloed van die subjek en taal self is daar verbygegaan. Met die ineenstorting van die metaverhaal bly egter nou nog net die enkelverhaal, die meer beskeie verhaal, die partikuliere verhaal van flitsende, verbygaande beelde en fragmente oor, gedring deur slegs nog 'n figurale energie.

Hierdie stemming in Lyotard se filosofie word reeds met die verskyning van die Engelse vertaling van The Postmodern Condition geproblematiseer, wanneer die outeur van die voorwoord in The Postmodern Condition, die gevierde literêre teoretikus Frederic Jameson, Lyotard skerp daarvoor verkwalik dat hy geen aanvoeling getoon het vir die aansprake van wat genoem sou kon word 'n "Franse post-Marxisme" nie (Lyotard 1984:x). Volgens sodanige post-Marxistiese perspektief is die metaverhale van die moderne nié verdaag soos Lyotard meen nie, maar het dit effektief ondergrondse karakter verkry, waar mag en kontrole oor begrippe soos waarheid en geregtigheid steeds beheermatig (dit is, kapitalisties) ingerig word, maar subversief en dus nie as sodanig herkenbaar nie. Die profytlike monopolisering van inligting deur ultra-kapitalistiese maatskappye soos Microsoft, Apple en Oracle is vir Jameson die duidelikste voorbeeld van hierdie nuwe beheersoeke oor waarheid en geregtigheid (Lyotard 1984:xiii), maar dan in gekamoefleerde sin, as iets wat te make het met die vloei van inligting, flitsende beelde, onmiddellike kommunikasie, uiteindelik met "persepsies van waarheid". Jameson beweer op sterkte van die onwilligheid van Lyotard om hierdie gerepresseerde kwaliteit van beheer oor waarheid en geregtigheid in die era van die "beeld", die era wat Jameson kenmerkend "laat-kapitalisme" noem, te herken, dat Lyotard geensins nog van die moderne afskeid geneem het nie, maar steeds onbewustelik in die logika van die moderne bly vassteek. Lyotard herken nie die vermoë van die metaverhale, wat hyself geïdentifiseer het, om sigself te kamoefleer onder die vaandel van "inligting", "kommunikasie" en uiteindelik "persepsies" nie. Kortom, Jameson beweer dat epistemologie na Lyotard se analise weldra plek sou moes maak vir perseptologie. Die waarheid het plek gemaak vir 'n beeldekamoeflering van die waarheid; en geregtigheid, sekerlik dié uitstaande Marxistiese motief, het plek gemaak vir beeldmatige en manipulerende persepsies van geregtigheid.

Uiteraard is Jameson as pertinent materiële denker in die Marxistiese tradisie baie skerp teë op hierdie perseptologiese perspektief op waarheid en 
die figurale disseminasie van kennis, selfs nog meer verbete in sy latere en meer onlangse werke soos Postmodernism, or, the Cultural Logic of Late Capitalism (1992) en A Singular Modernity (2002). Jameson dui juis aan dat 'n opvatting van die waarheid as "persepsie" of "beeld", derhalwe digitaliseerbaar en toenemend kapitaliseerbaar, die logiese, hoewel ekstreme, konsekwensie van Lyotard se analise is. Dit beteken dat waarheid en geregtigheid toenemend minder belangrik sal word, maar persepsies en die manipulering van persepsies aangaande begrippe soos "waarheid" en "geregtigheid" toenemend belangriker.

Die waarskuwings van Jameson ten aansien van 'n post-Lyotardiaanse kapitalisering van waarheid, bemiddeld deur die verspreiding van "inligting" en die "beeld", resoneer met die geniale Britse filosoof Christopher Norris se skerp identifisering en afwysing van die malaise, sinisme en (politieke) apatie wat die kultuurkritiek van die sogenaamde postmoderne diskoers ná Lyotard kenmerk (vgl Norris 1993, 1998). Norris se kritiek van die postmoderne is idiosinkraties en moet versigtig gelees word. Hy is terselfdertyd 'n vurige kontra-postmodernis én 'n uitgesproke Derridiaan en het juis reeds baie vermag om die resepsie van Derrida se werk los te maak van die sogenaamde "postmoderne diskoers" (vgl Norris 1993:49 ev; 134 ev), waarbinne die gevierde Frankfurtse filosoof, Jürgen Habermas (1987), Derrida self plaas en waarteen hy so skerp te velde getrek het. Norris dink daarenteen aan Derrida as 'n "ander soort" moderne denker. Norris (1998:164 ev) bespreek in sy werk What's Wrong With Postmodernism, in 'n hoofstuk betekenisvol getitel Lost in the Funhouse, die gebrek aan erns ten opsigte van analise, metode en filosofiese deeglikheid in die tradisie wat ná Lyotard in die Franse en later wyer Europese filosofie ontwikkel het. Norris se beswaar teen die "filosofiese" tradisie wat vanuit Lyotard se futurologiese kultuuranalise ontwikkel het, sou saamgevat kon word in die begrip innuendo. Hiermee bedoel Norris dat temas in die filosofie ingevoer word wat nie berus op analise nie, maar op perseptologiese stemmingmaking: Die waarheid berus volledig op konsensuswaardes, en dan spesifiek in die gedaante van beeldmatige lobbying, waardeur die potensiële konsensus gestu kan word, en die soeke na waarheid niks anders word nie as 'n speelse, estetiserende roesparty, 'n herdigitalisering van die werklikheid, 'n soort kunsfilosofiese Scrabble.

Norris tree heftig in debat met dié volgens hom onwaaragtige opvatting van waarheid wat by 'n denker soos Jean Baudrillard aangetref word.

Baudrillard, by wie ons aanstons sal vertoef, verklaar dat die wêreld na moderniteit selfs nie net ' $n$ wêreld van beelde is nie, maar nou reeds al van nabootsings van beelde: "Dit wil voorkom of die meeste mense nie begryp nie dat ons in in 'n epog inbeweeg het, waar die waarheid volledig 'n produk van beelde en konsensuswaardes is" (Baudrillard, gesiteer in Norris 1993:169). Waarheid is dus bloot 'n effek van intersubjektiewe instemming in 'n 
beeldnabootsende leefwêreld. Norris beskou hierdie soort uitspraak as sou dit radikaal mank gaan aan die soort filosofiese erns en soberheid waarvan die Westerse filosofie 'n register wil bied en dat hierdie estetiese spel met innuendo en die gepaardgaande verlies aan metodiese deeglikheid en analise, fatale gevolge inhou vir die Westerse samelewing se selfbegrip as sodanig.

Beide Jameson en Norris se kritiek van die uitdruklik "postmoderne" (dit wil nou sê, die tradisie pertinent ná Lyotard) resoneer op hulle beurt aanvanklik waarskynlik onbedoeld met die stem van Habermas. Habermas verset hom duidelik in die tagtigerjare met sy teks Der philosophische Diskurs der Moderne teen die radikaliteit van wat hy ingelyks waarneem as 'n volkome gebrek aan erns waarmee die vraag na die filosofiese vraagstelling self benader word. Meer as een maal in die teks, trouens bykans refreinmatig, spreek Habermas die vraag uit of sogenaamde "postmoderne" denkers die erns en potensieel fatale implikasies van hulle radikalisering van Lyotard se kultuuranalise begryp. Die tipies eietydse aanbeveling dat filosofiese denke van die probleemoplossende aard en noodsaaklike maatskaplike onrustigheid daarvan onthef moet word en eerder die spekulatiewe aard van "literêrteoretiese" refleksie behoort aan te neem, dus 'n stilistiese of estetiese eerder as 'n maatskappykritiese opgaaf voor oë moet hou, uiteindelik selfs geheel 'n estetika moet word, dui vir Habermas op 'n katastrofale gebrek aan insig in die uiteinde van hierdie speelse, karnavalistiese proses, naamlik die onmoontlikheid om uiteindelik nog enige iets betekenisvol oor die geleefde lewe kwyt te raak (vgl Habermas (1987a:294ev; 408[nota 28]). Habermas meen dat die wesenlike filosofiese problematiek en filosofiese statusaansprake in ons tyd onherkenbaar vermink is. Die uitdaging bly vir Habermas geleë in die oordenking van die rede in terme van die rede se sosio-historiese begrensdheid. Anders gesê: Om met inagname van die historiese en maatskaplike gebedheid van die kennende en handelende subjek krities geïnteresseerd te bly in begrippe soos waarheid, geregtigheid en skoonheid.

Die vraag na hierdie erns, of die verlies daaraan, is op 'n spits gedryf meer as 15 jaar nadat Habermas die verlies aan hierdie erns betreur het in Der philosophische Diskurs der Moderne, op 'n herfsdag in New York City. Op 11 September 2001 verander ons leefwêreld. Daar was ineenstorting in meer as een opsig daardie dag. Nie net was daar fisiese ineenstorting nie, maar daar het ook 'n metafisiese ineenstorting plaasgevind; 'n ineenstorting van konsepte waarmee ons gemeen het ons vertroud is. Dit sluit in ons begrip van veiligheid en geregtigheid, asook ' $n$ antagonisering van hierdie begrippe. Nie net het die wêreld verander op 11 September 2001 nie, ook ons begrip van die antagonisering van dit wat wesenlik tot die leefwêreld geag kan word, het 


\section{Terreur, roes en ordes}

verander. Daar was sedert die Tweede Wêreldoorlog geen meer dramatiese verwysingspunt ten aansien van die gebrokenheid van die moderne wêreld, van die opponeerbaarheid van die moderne wêreld, as 11 September nie.

Enkele weke na die aanval op die World Trade Center en Pentagon, voer Giovanna Borradorri gesprek met die twee grootste lewende filosowe van ons tyd, te wete Habermas self en Jacques Derrida, ${ }^{3}$ in New York City. Nie ver van waar die aanval op die tweelingtorings plaasgevind het nie, praat hierdie twee denkers oor die noodsaak van 'n heroorweging van die begrip "geregtigheid". Die twee onderhoude met Habermas en Derrida by hierdie geleentheid in New York is uiteindelik in boekvorm gepubliseer, getitel Philosophy in a Time of Terror: Dialogues With Jurgen Habermas and Jacques Derrida (Borradori 2003). Derrida en Habermas vind mekaar verrassend genoeg in hierdie onderhoude baie duidelik oor 'n aantal sake.

Die eerste saak waaroor Habermas en Derrida konsensus het, is dat filosofie 'n onontbeerlike bydrae behoort te lewer tot 'n nuwe verstaan van terreur, sowel as 'n heromlyning van die begrip "geregtigheid". Hulle het ook konsensus daaroor dat terreur reeds die mees prominente sosiale merker van die $21^{\mathrm{e}}$ eeu is, net soos wat kolonialisme en totalitarisme die geskiedenis van die $19^{\mathrm{e}}$ en $20^{\mathrm{e}}$ eeue deurslaggewend bepaal het. ' $\mathrm{n}$ Verdere punt van konsensus is dat die begrip "terrorisme" om velerlei redes 'n suspisieuse begrip is, veral omrede die begrip so onverbloemd ideologies deur sowel aanvaller as slagoffer ingespan word. Daarom is die verrassende in die boek dat beide Habermas en Derrida met konkrete voorstelle vorendag kom in terme waarvan 'n breuk bewerkstellig kan word met sowel die klassieke opvatting van 'n begrip soos "terreur", veral ten opsigte van die retoriese, politieke en sosiale polarisasie tussen goed en kwaad wat in die begrip opgesluit lê, as die klassieke opvatting van die nasie-staat in die internasionale reg, sou dit byvoorbeeld veel meer deugdelik wees om eietyds te verwys na die kosmopolitaanse en juridiese werklikheid van kontinentale alliansies. Nie Derrida of Habermas huiwer dus hier om konkreet oor "geregtigheid" binne die konteks van sosiale terreur in die vroeg $21^{\mathrm{e}}$ eeu te probeer praat nie.

Beide laat hulle egter ook uit oor die feit dat wendinge in die filosofie self die afgelope vier of vyf dekades, maar spesifiek die afgelope 10 of 15 jaar, dit baie moeilik maak om nog betekenisvol en deurleefd oor geregtigheid te praat. Die filosofiese waarde van 11 September, sou 'n mens dalk na die onderhoude met hierdie twee denkers in New York kon sê, is dat dit aandui

\footnotetext{
${ }^{3}$ Jacques Derrida is inmiddels op Vrydag 8 Oktober 2004 (enkele weke nadat hierdie voordrag aangebied is) oorlede.
} 
juis in watter diep vaarwaters begrippe soos "waarheid" en "geregtigheid" beland het. Of anders gesê: hoe laat in die nag dit by die Rauschfest van die postmoderne geword het, waar begrippe soos waarheid, geregtigheid en skoonheid skynbaar niks meer is nie as speelkaarte in 'n makabere pokerspel sonder rigting of einde.

Juis die reaksie van Jean Baudrillard, die mees sentrale en radikale denker in die post-Lyotard tradisie, op die gebeure van 11 September, dui aan hoe laat dit werklik by die roesfees geword het. Baudrillard se werk word baie wyd gelees en hy het in sekere sin 'n oorgepubliseerde denker geword. Hy skryf en publiseer self nie net baie en op baie verskillende plekke nie, maar baie word oor sy standpunte geskryf en nagedink. Baudrillard het 'n penchant vir ironisering en sound bytes, hy is die postmoderne vergestalt, hy is díe idool van die kwasi-intellektuele popkultuur van ons tyd.

Baudrillard se reaksie op die terreur van 11 September is heeltemal konsekwent met dit wat hy gedurende die 1990's in sy vele sogenaamde kultuurkritiese publikasies beweer het, naamlik dat daar geen werklike wêreld is nie, slegs maar ' $\mathrm{n}$ wêreld van nabootsings, van beelde wat ander beelde naboots, dat niks nuut of outentiek is nie, dat alles reeds gebeur het en juis daarom niks eintlik reeds aan die gebeur is nie. Nie sonder probleme nie, identifiseer Baudrillard vroeë moderniteit as die periode tussen die Renaissance en die Industriële Revolusie, moderniteit as die periode wat met die begin van die Industriële Revolusie ' $n$ aanvang neem en postmoderniteit as die periode van die opkoms van die massamedia en die sentralisering van die "beeld". Baudrillard beskou homself as protagonis van die "beeld" en dan ook, onbeskroomd selfverwysend, as een van min werklik postmoderne denkers, trouens, en nie sonder ironie nie, die eerste outentieke postmoderne denker, die eerste en een van aanvanklike min wat Jameson en Norris se soort kritiek wil weerstaan, een van die aanvanklike min wat kans gesien het vir die logiese konsekwensies van Lyotard se futuristiese kultuuranalise (Baudrillard 1995b:33).

Baudrillard se resepsie van 11 September koppel terug met 'n ouer "analise", te wete dié van die Golf-Oorlog in 1991, waaroor hy 'n boek geskryf het, getitel The Gulf War did not take place. Baudrillard is heeltemal ernstig wanneer hy beweer dat die Golf-Oorlog nie plaasgevind het nie. Volgens Baudrillard is oorlog, om die heel minste te sê, nie meer wat dit eens was nie. Oorlog is nie meer, soos in die voor-moderne en in die moderne tyd, die resultaat van onopgeloste politieke argumente wat in fisiese geweld eindig nie. Die Koue Oorlog beginsel van Wedersyds Versekerde Vernietiging (Mutually Assured Destruction) het volgens Baudrillard oorlog weg van die werklikheid van fisiese Zerstörung na die domein van die virtuele werklikheid 
gevoer. Oorlog is nie meer ' $\mathrm{n}$ clash of brutes nie. Nee, dit is 'n geprogrammeerde operasie wat uitgevoer word aan die hand van 'n vooraf-gedefinieerde model, ' $n$ oorlog van sagteware. Die VN troepe het telkens nie gereageer op die werklike vermoëns van die Irakese leër nie, maar telkens bloot 'n plan uitgevoer wat vooraf per sagteware bepaal is. Met ander woorde, die VN troepe het nie in die konvensionele en tradisionele sin waarvolgens oorlog verstaan (en gevoer) is, Irakese vuur met vuur beantwoord nie, maar eintlik oorlog gemaak teen radartekens, GPS-koördinate, satellietfotos, infrarooi beelde, en so meer. Hierdie is nie slagordes nie, maar net tekens, beelde. Die VN het volgens Baudrillard in 1991 wesenlik ' $n$ virtuele oorlog met skerppunt ammunisie gevoer, missiele is gerig op kolletjies op 'n radarskerm en woorde soos troepe-aflewering en missielplasing was veel eerder aan die orde as, argumentshalwe, die lot van die sogenaamde onbedoelde teiken.

Die Golf-Oorlog is volgens Baudrillard die perfekte illustrasie van die wyse waarop die beeld, en die laagstelling van beeld óp beeld, die volgens hom "sogenaamde werklikheid" in die eietydse kultuurbegrip vervang het. Die Golf-Oorlog was 'n oorlog van informasiebeelde, CNN nuusflitse en lewendige video-uitsendings van missieltrajekte, as sodanig bloot nóg 'n mediaverskynsel, net nóg beelde. Natuurlik sou Baudrillard toegee dat daar ágter die beeld duisende dooie vrouens, kinders en (steeds) soldate lê, máár dit is nie meer wesenlik nie. Die wesenlike ís die beeld. Wie diegene wat gesterf het was, wat die aard van die dood was wat hulle gesterf het, is nie tersake nie. Dit maak nie langer saak nie. Die werklikheid is, om Baudrillard se gevierde woord te gebruik, nie meer werklik nie. Die werklikheid ís die beeld, die persepsie. Wie weet of die oorlog wel werklik plaasgevind het? Hoe sou 'n mens kon weet of dit nie 'n studio-opname in Hollywood was nie? Niemand sal nie weet nie. Hét die oorlog plaasgevind? Wie gee nog om?

Myns insiens belangrik is dat Baudrillard hierdie beeldsentralisering nie bloot beskryf nie. Hy is subtiel en verleildbesig om aan die beeldnabootsing mee te werk. Hy neem deel aan die laagstelling van die beeld. Deur te weier om in gerig te tree met die beeld, die beeld te ontdigitaliseer, die beeld in kritiese heroënskou te neem of selfs af te takel deur die reële, geleefde lewe van elke gefotografeerde slagoffer in daardie oorlog onder die loep te neem, doen hy mee aan die sentralisering en bestendiging van hierdie beeldebegrip. Sy onwilligheid om dit te analiseer op sterkte van daadwerklike lewensverlies, in terme van geleefde lewens, laat hom in die ruimte van innuendo. Wie gee om of die oorlog regtig plaasgevind het? Die vrou wat haar kind sien doodbrand het, dalk? Of die kind wie se bene afgeskiet is? Of die eggenote van 'n vegvlieënier wie se F-18 - of was dit dalk net 'n kruisie op 'n radarskerm - skielik opgehou flikker het op die skerm? 
Baudrillard ontstel my, omdat hy niks oor die reuk van bloed skryf nie ${ }^{4}$. Hy skryf oor die simulacra in die gefolterde taal van kontinentale filosofie. Hy skryf nie oor rook, vuur en oopgekraakte skedels nie. Daar is tussen Baudrillard in sy studeerkamer en die vegvlieënier wat 'n dodelike missiel per sagteware en infrarooi toerusting aflewer, geen verskil nie. Albei is besig met 'n Playstation-speletjie. Die gebeure van vroeg 1991 in Irak het volgens Baudrillard self so min met oorlog te make as pornografie met seks. Vir hom is dit 'n verskynsel wat pertinent esteties ondersoek behoort te word, trouens nog net esteties ondersoek kán word, niks meer of minder nie. Die verbygaan van die diep menslike, ekonomiese en strategiese redes vir die oorlog hinder hom nie. Die vraag na geregtigheid vra hy glad nie. Die volle waarheid van bloed en trauma voor, tydens en na hierdie oorlog verdwyn onder die gewig van sy meedoënlose abstraksie.

Die teoretiese grondslae van hierdie perspektief word ietwat later deur Baudrillard in sy topverkoper, Simulacra and Simulation (Baudrillard 1995b) uiteengesit. Dit is 'n digte, prosaïese teks, gesofistikeerd en subtiel. Juis hierdie verleidelike prosaïese kwaliteit maak dit uiteindelik so 'n vreesaanjaende teks. Volgens Baudrillard geskied werklikheidskontruksies vandag meer as ooit tevore aan die hand van mites of konseptualiserings. Vandag het ons volgens hom reeds te make met "hipermites". Hipermites het volgens hom geen binding aan die werklike werklikheid nie. Die fyn lyn tussen die konsep en die werklikheid, die teken en die betekende, stort as't ware in die konsep self na benede en al wat oorbly, is wat Baudrillard die "hiperwerklikheid" noem. Baudrillard skryf:

No more mirror of being and appearances, of the real and its concept ... No more imaginary coextensivity: it's genetic miniaturization is the dimension of simulation. The real is produced from miniaturized cells, matrices, and memory banks and models of control, and it can be reproduced an indefinite number of times from these. It no longer needs to be rational, because it no longer measures itself against either an ideal or negative instance. It is no longer anything but operational. In fact, it is no longer really the real, because no imaginary envelopes it anymore. It is a hyperreal, produced from a radiating synthesis of combinatory models in a hyperspace without atmosphere.

(Baudrillard 1995b:2, my kursivering)

\footnotetext{
${ }^{4}$ Allermins is ek besig om die boodskapper vir 'n ontstellende boodskap te verkwalik. Baudrillard sou natuurlik sê dat as jy nie bloed ruik nie, ruik jy dit nie, ontstellend soos dit is. Sy punt is juis dat dit nie meer moontlik is om bloed te ruik nie. My punt is dat iémand, êrens, wel nog bloed ruik en solank as wat die reuk van bloed wel nog deel uitmaak van 'n geleefde lewe, die reuk van bloed steeds deur filosowe met êrens geneem moet word en nie obsoleet verklaar kan word nie.
} 
Hierdie hiperwerklikheid stuur volgens Baudrillard onafwendbaar op verwarring, disoriëntasie en apatie af:

The territory no longer precedes the map, nor does it survive it. It is nevertheless the map that precedes the territory - precession of the simulacra - that engenders the territory, and if one must return to the fable, today it is the territory whose shreds slowly rot across the extent of the map. It is the real, and not the map, whose vestiges persist here and there in the deserts that are no longer those of the Empire, but ours: The desert of the real itself.

(Baudrillard 1995b:1)

Wat Baudrillard wesenlik hiermee sê, is dat die referent dood is. Die referent het verdrink in die see van simulacra. Met die afsterwe van die referent, bly alleen nog maar simulasie en simulacra oor. Wat is die implikasie hiervan? Ten opsigte van waarheid en geregtigheid, is die implikasie uiterste desolasie, die "woestyn van die werklikheid", waarna Baudrillard so pas verwys het (ook Baudrillard 1995b:6).

Want presies dieselfde destruktiewe logika herhaal sigself wanneer Baudrillard uiteindelik aandag skenk aan die aanvalle op 11 September in sy latere teks, The Spirit of Terrorism (2003). Baudrillard oorweeg in sy teks nogmaals nie die vraag na geregtigheid nie. Hy gaan by die reële lotgevalle van die duisende slagoffers in die Twin Towers, Pentagon en gekaapte vliegtuie verby. Veel meer is Baudrillard geïnteresseerd in die estetika en simboliek van die aanvalle, die beelde daaromtrent, die operasionele kwaliteit van die mediadekking. Serebraal koudbloedig fokus Baudrillard op die aanval as "slagtingsimboliek", waarin die hijacker voorgestel word as die perfekte simbool van die klassieke offerande, wat, gekombineer met Westerse hoëtegnologie vermoëns, nie bloot aanval nie, maar eerder die eietydse beskawing as estetiese gebeure "ontmasker". Die gebeure van 11 September moet volgens Baudrillard dus as by uitstek esteties verstaan word, waar 'n oor-gesofistikeerde Weste op die knieë gebring word juis deur nieWesterlinge, met juis enantiodromia, die tegnologiese produkte - en beelde van die Westerse samelewing. Die krag en impak van die aanval is voorts nie geleë in die duisende onskuldige mense wat dood is nie, maar in die mediadekking daarvan, die spektakel, die beeld, iets waarop die aanvallers volgens Baudrillard pertinent gereken het. Tevergeefs soek 'n mens in hierdie teks na mededoë, 'n simpatieke blik, 'n morele keuse om hierdie verskriklike daad as een van onreg uit te wys. Die terroris, die terreurmaker, tree in hierdie teks na vore as 'n skerp kultuurkritikus en esteet, terwyl nooit vertoef word by 
die geldigheid van die vraag na geregtigheid in hierdie konteks of selfs verwante sosiale kontekste, soos 3/11 (Madrid 2004) nie.

Aan die einde van hierdie ontstellende teks, ontken Baudrillard weer, soos met die Golf-oorlog, die "gebeurtenis" daarvan, terwyl hy dit weer en nou voorspelbaar so, toevou in die volgens hom pseudo-natuur van enige gebeurtenis wat met intensiewe mediadekking gepaardgaan, 'n geval van die beeld wat die gebeure konsumeer. Terrorisme is volgens Baudrillard immoreel, maar net in soverre die beskawing self immoreel is. Baudrillard skryf:

The World Trade Center event, that symbolic challenge, is immoral, and it is a response to a globalization that is itself immoral. So let us ourselves be immoral; and if we want to have some understanding of all this, let us go and take a little look beyond Good and Evil ...

(Baudrillard 2003:xx)

Dit klink mooi Nietzscheaans, nie waar nie? Maar was dit nie juis Nietzsche wat ook beweer het dat martelaarskap die vyand van die waarheid is nie? Vir Baudrillard is terrorisme niks anders nie as 'n outentieke antwoord op vrae wat die Westerse samelewing self na vore gebring het.

Ook The Spirit of Terrorism is 'n gesofistikeerde, verleidelike teks. Bykans poëties beskryf Baudrillard 'n sisteem wat worstel om sigself te universaliseer en daarin faal. Dit wat ons "terrorisme" noem, is syns insiens 'n natuurlike virus, 'n onafwendbare partikuliere verset teen 'n universaliserende credo. Globalisering is tans in worsteling met sigself, nadat dit in New York die simbolies perfekte uitklophou toegedien is. Opvallend beskou Baudrillard nie die aanval as sodanig as perfek nie, maar juis die induiestorting van daardie twee massiewe wolkekrabbers. Baudrillard kon nie vir 'n beter simbool vir die selfmoord van die Weste gevra het nie, selde was poësie volgens Baudrillard so kragtig, so esteties, so getrou aan die "waarheid":

Imagine they had not collapsed ... the effect would not have been the same at all. The fragility of global power would not have been so strikingly proven. Seeing them collapse themselves, as if by implosion, one had the impression that they were committing suicide ...Their symbolic collapse brought about their physical collapse, not the other way around ... Their nerves of steel cracked. They collapsed vertically, drained of their strength.

(Baudrillard 2003:xx) 


\section{Terreur, roes en ordes}

Baudrillard is kennelik verlig oor die vernietiging van dit wat hy elders noem "argitekturele monsters" en gaan selfs so ver om, in betreklik swak smaak vir 'n esteet nogal, te beweer dat die verskriklike dood van die 4000 slagoffers korrespondeer met die verskrikking wat hulle moes ervaar om elke dag in daardie volgens hom afskuwelike geboue te moes leef en werk. Hy verloor homself selfs ietwat in hierdie verstommende kwinkslag, soos wat hy homself telkens verloor in sy eie universum van simboliese verbeelding: Daardie universum waar niks swart of wit of veilig of logies is nie; daardie Baudrilliaanse universum waar niks waar is en niks werklik van onreg kan spreek nie; daardie spektrale, verwarrende, waansinnige woestyn van die werklikheid. Dit is die simboliese universum van Baudrillard waaroor hy talle topverkopers geskryf het, waar die werklikheid slegs nog ideologies en esteties geweeg word, waar Menschlichkeit met 'n beduidende mate van leedvermaak verironiseer word. Vrouens, volkome oorval deur die monsteragtigheid van die werklike gebeure van vallende liggame en die reuk van brandende mensevlees, wat hulle hare fisies uit hulle koppe trek in die strate van New York, val Baudrillard onesteties, selfs afsigtelik op. Hy kies eerder om te fokus op die simboliese einde van 'n argitekturele Janustweeling wat hy verpes.

Baudrillard se meedoënlose estetika is besig om 'n nuwe tradisie in die filosofie te ontplooi waaraan ek 'n massiewe afkeur wil boekstaaf. Boonop vermoed ek dat die 2003-uitgawe van die Irak-verhaal Baudrillard se eie nabootsing van beelde pertinent ondermyn. Die hewige reaksie vanuit die internasionale gemeenskap - en later vanuit Demokratiese geledere in die VSA self - teen die oorlog in Irak, ten aansien van wanvoorstellinge, politieke opportunisme en die manipulering van inligting, dui juis daarop dat mense werklik nog in staat is om buite-om beelde te dink en die geleefde lewe raak te sien vir wat dit is; nog in staat is om die post-Marxistiese kamoefleerverf af te krap. Indien Baudrillard se teorie waar was, sou dit nie moontlik gewees het om die wanvoorstellinge en manipulering van inligting ten opsigte van byvoorbeeld beweerde wapens van massavernietiging te identifiseer nie. Die feit dat mense ook buite-om gevestigde politieke raamwerke as't ware deur die beeld kon sien, bevraagteken die geldigheid van die opvatting dat die beeld sy eie suiwer simulacrum is.

Om meegaande ook na twee onmiddellike eksponente in die cumBaudrillard, post-Lyotard tradisie te verwys: Twee begaafde en opkomende Europese kultuurfilosowe, Paul Virilio en Slavoj Zizek, stap bykans tree vir tree op die spoor van Baudrillard se "estetiese" afweging van 11 September 2001. Die betreklik subversiewe uitgewer Verso, publiseer as drieluik saam met Baudrillard se The Spirit of Terrorism, die teks van Virilio, Ground Zero 
(2002) en die teks van Zizek, Welcome to the Desert of the Real: Five Essays on September 11 and Related Dates (2002), laasgenoemde 'n direkte heenwysing na Baudrillard se bogenoemde "verwelkoming in die woestyn van die werklikheid". Van die drie bly Zizek vir my die mees leesbare en, indien ek die woord so laat in die nag steeds mag gebruik, "verantwoordelike" kritikus.

Virilio daarenteen, van beroep 'n argitek en stadsbeplanner, se teks is bleek en uitsigloos. Ruimte ontbreek om die teks hier geanaliseerd aan die orde te laat kom, maar die teks laat 'n mens met werklik niks na 11 September nie. Virilio is daarvan oortuig dat dit wat na die gees van die Aufklärung "vooruitgang" genoem is, eenvoudig tegnologiese progressie behels wat die mensheid self toenemend marginaliseer. Hy illustreer die opvatting met talle verwysings na die intense verhouding tussen kommoditeite, kuns en die media in die eietydse Westerse kultuur. Vooruitgang behels syns insiens nie langer die opvatting van 'n mensheid wat braaf die toekoms tegemoet gaan nie, maar deur hulle eie maaksels vernietig word. Nie minder serebraal as Baudrillard op sy mees meedoënlose nie, word die begrip "terreur" derhalwe by Virilio ingespan as 'n verskynsel waarvoor die Westerse samelewing self verantwoording moet doen, en nie die sogenaamde terroriste nie. Al-Kaïda figureer in die teks bloot as agent van nostalgie, 'n simbool van die verwording van die werklikheid. Nie een maal in Virilio se koue teks tref ons 'n direkte, teenspraakvrye afwysing van die terreurdaad self aan nie. Die daad van terreur op 11 September behoort ons volgens Virilio te herinner dat ons, die Westerlinge, verword het. Die aanval was dus 'n simboliese, as ' $t$ ware 'n introspektiewe daad. Al-Kaïda het ons, die Westerlinge, met hierdie aanval 'n massiewe guns bewys, naamlik om ons te dwing om die vraag na die geldigheid van ons begrip van vooruitgang te vra. Regtig? Werklik, dan lees ek veel eerder Adorno en Horkheimer se Dialektik der Aufklärung om sodanige premisse behoorlik geanaliseerd aan die orde te sien kom. Virilio se Ground Zero het zero met die gelokaliseerde Ground Zero te make. Sy diskoers lewer 'n zero bydrae tot ' $n$ analise van die waarheid van bloed en trauma op 11 September.

Ek moet op hierdie punt erken dat my geduld met hierdie smaaklose soort nihilisme en pedantiese skynestetika uitgeput is. Die aanval van 11 September was 'n sluwe, wrede en lafhartige daad teen onskuldige mense wat koffie gedrink en werk toe gegaan het. Punt. Ek verseg om meer daarin te wil lees. As die einde van my geduld met hierdie nou reeds voorspelbare gedreun oor die ondergang van die Westerse selfbegrip en die verheerliking van die terroris as estetiese agent tot selfondersoek, 'n soort edele agent provocateur, van my 'n kulturele ortodoksis of reaksionêr maak, aanvaar ek dit gelate. Want na Virilio is daar werklik niks meer om te sê nie, behalwe om 


\section{Terreur, roes en ordes}

voortdurend en vanuit 'n verskeidenheid van premisses te beaam dat daar niks meer is om te sê nie. En tog bly ek oortuig dat filosofie as ernstige dissipline meer het om te bied as dit wat Baudrillard en Virilio bied, veral na en gesien in die lig van 11 September.

Zizek se teks is veel meer genuanseerd en minder ontstellend as dié van Virilio. Zizek se premisse in sy werk, Welcome to the Desert of the Real, is dat die groot flater wat die Verenigde State ná 11 September gemaak het, was om sigself as "slagoffer" te beskou. In stede daarvan om die aanval te gebruik as 'n insentief om buitelandse betrekkinge in heroënskou te neem, het die Verenigde State vuur met vuur beantwoord, 'n strategie wat, soos ons nou reeds by Baudrillard gesien het, in hierdie beeldobsessiewe, "postmoderne" geledere as teenproduktief en selfs onsinnig beskou word. Die enigste wyse waarop volgens Zizek verhoed kan word dat 'n soortgelyke aanval weer op Amerikaanse turf plaasvind, is om 'n beeldherhaling daarvan te verhoed; dus voorsorg te tref dat dit ook op geen ander plek ter wêreld sal plaasvind nie. Vir hulle wat onherroeplik onder die betowering van hierdie soort verskyning van "postmoderniteit" is, mag dit dalk substansie dra, maar ek persoonlik vind dit 'n verstommend naïewe gedagte. Zizek is nietemin veel meer genuanseerd as sy twee medegangers oor onder meer die onverbloemde Schadenfreude ten aansien van Amerikaanse lyding op 11 September. Minstens word dít darem in sterk taal afgewys. Ook veroordeel Zizek die verheerliking van Palestynse selfmoordbombardiers en vergryp hy hom nie aan die estetisering van die (self)moorddaad as "simboliese en estetiese offerhandeling" soos Baudrillard nie. Zizek skryf ook uiters insiggewend en gebalanseerd oor die aard van Westerse vis-à-vis Islamitiese fundamentalisme. Tog, ook by Zizek, tref ons 'n duidelike onwilligheid aan om oor die onreg van die aanval as sulks uit te wei. Ook in sy diskoers figureer die begrip "geregtigheid" nie. Ook Zizek huiwer voor die waarheid van bloed en trauma op 11 September.

Ek verlang vandag meer as ooit tevore na die avontuurlus, maar veral na die legendariese erudisie en kultuurkritiese insig van Michel Foucault. Wat sou Foucault van 11 September gemaak het? Daaroor sou ons seker net kon spekuleer. Maar Michiel Leezenberg, 'n Amsterdamse navorser in die filosofie van Islam, toon onlangs aktueel aan in welke mate Foucault die spirituele dinamika van Islam aangevoel en 'n radikale gebeurtenis soos die slagting van 11 September vooruitgeskat het. Leezenberg se artikel, "Power and Political Spirituality: Michel Foucault on the Islamic Revolution in Iran" (2004:99-115), plaas Foucault se "ideëjoernalistiek" oor die revolusie in perspektief en omlyn ineens ook implikasies van Foucault se denke vir 'n begrip van die magshandelinge van Islamitiese faksies in 'n eietydse Westerse wêreld. Leezenberg (2004:101-104) toon aan dat Foucault se 
analise van die revolusie, naamlik dat die gebeure in Iran 'n radikaal nuwe probleem ten opsigte van die begrippe mag, politiek, religie en spiritualiteit geformuleer het, volkome korrek was. Foucault was naamlik sensitief vir die nuwe stemme van verandering in Iran op 'n stadium toe Westerse intellektuele bykans sonder uitsondering hierdie beweging in Islam as regressief en as 'n terugval na die pre-moderne bestempel het. Foucault was besonder geïnteresseerd in die spiritualiteit van die massas wat teen die orde in opstand gekom het. Foucault sou die gebeure dan ook ontleed as 'n soort politiek wat in verset gekom het teen gevestigde moderne politieke analises sowel as ' $n$ verset teen moderne regimes van onderdrukking, kontrole en beheer. In 'n tyd waar dit dringend noodsaaklik geword het om die komplekse wêrelde van Islam te karteer, het Foucault reeds, deur te fokus op 'n analise van die politiek van die betrokke religie, parameters aangelê om hierdie kartering met inagname van die idiosinkrasieë van mag, spiritualiteit en gehoorsaamheid in Islam, te kan begin. Deur tipies-Westerse vooroordele ten opsigte van rasionaliteit en die kontrole van die individu opsy te skuif, kon Foucault intelligente en deurdringende vrae ten opsigte van die revolusie stel. Wat het in ons tyd geword van hierdie parrhesia, die klassieke gewilligheid en vermoë om die waarheid ten spyte van die waarheid te wil vertel? Foucault est mort! Inderdaad.

Ek vind die huiwering voor die waarheid van trauma en die sublimerende misbruik van die begrip "skoonheid" toenemend onleefbaar en onhoudbaar. Watter redelike mens sou vir 'n oomblik dink dat die Verenigde State nié sou reageer nie? Watter soewereine staat op enige plek sou nié retalieer nie? Hoe is dit soortgelyk moontlik dat van die regering in Israel verwag word om nie op te tree teen mense wat moord ideologies estetiseer met verwysings na die paradys en 'n duisend maagde nie? Ek minag nie die kompleksiteit van die sosio-historiese omstandighede op die Wes-oewer nie, eweneens skort daar drasties baie met die Verenigde State se buitelandse beleid (vir dekades reeds), maar ek twyfel of 'n estetiese verantwoording van berekende moord, die berekende en opsetlike neem van menselewens, op enige plek buite hierdie "postmoderne estetisering" van brutaliteit duldbaar sou wees.

Ek stem daarom met Habermas saam dat die waarde van 11 September, indien daar wel iets waardevol aan so 'n makabere dag kan wees, daarin geleë is dat dit die aandag vestig op juis hoe uitgebrand begrippe soos waarheid en geregtigheid in ons tyd geword het - en hoe misbruik die skoonheidsleer geword het. Trouens, waarheid en geregtigheid het in ons leefwêreld na die beskrywing van Baudrillard en genote, volkome wegdoenbaar geword, terwyl die ou-ou filosofiese begrip "skoonheid" gebruik 
word om die mees onverantwoordbare en veragtelike dade te sublimeer. Baudrillard reken 11 September is die dag waarop die postmoderne werklik "begin". Myns insiens weer, is 11 September juis die dag waarop die postmoderne roesparty tot uitbranding gekom het, die dag waarop die duur kristalglas laat val is en die gaste by hierdie dekadelange fees behoort te besef dat dit tyd is om huis toe te gaan. Ek kan dit dalk baie harder sê: 11 September getuig daarvan dat die praktiese rede in ons tyd tot op die punt van uitbranding verword het. Hierdie epistemologiese uitbranding of radikale verwording van die praktiese rede, sou ek altyd toegee, is 'n logiese konsekwensie van die moderne projek self. Reeds Sade het hierdie orgie van die postmoderne en die uitbrandingspotensiaal van die praktiese rede voorsien. Sade se orgiale heldin, Juliette, is veel meer as ' $n$ tintelende nimfomaan. Juliette is 'n simptoom van die krisis van die Kantiaanse projek, die feit dat die praktiese rede in 'n doodloopstraat beland het vanweë die morele en uiteindelik tegniese selfingenomendheid van die teoretiese rede. Om dit in Adorno se woorde te stel: Juliette beliggaam die doodloopstrate van die praktiese rede in die era van die instrumentele rede. Juliette demonstreer dus hoe die Verligting sy eie regressie konsekwensie-logies voortbring. Juliette is egter na 11 September 'n veel meer waaksame karakter as wat 'n mens by eerste lees van haar wedervaringe opval. Trouens, ek wonder tog of dit buitensporig sou wees om na Juliette as 'n vermanende karakter te verwys. Sy maan ons teen die afgrond waarvoor gehuiwer sou moes word, sy wys ons op die eksesse wat volg wanneer die praktiese rede uiteindelik verdaag word. Die vernaamste van hierdie eksesse is die heengaan van erns en soberheid in die filosofie.

Om hierdie deel van my polemiek af te sluit: Hoe billik is my lesing van Baudrillard, Virilio en Zizek? Sou Baudrillard in besonder nie eerder gelees moet word as 'n gesofistikeerde ontmaskeraar van 'n orde met 'n intrinsieke doodsdrang nie? Sou sy ironiserende, vermaskerde styl nie pertinent in so 'n lesing oorweeg moet word nie? Miskien sou ek my keuse van 'n polemiese lesing van Baudrillard, Virilio en Zizek kon rugsteun met verwysing na die begrippe waansin (of dan, Rausch) en werklikheid, wat so prominent in al drie hierdie skrywers se tekste figureer.

Ek sou my in hierdie opsig wou laat assisteer deur Luigi Pirandello se drama Henry IV, aanvanklik gepubliseer in 1922 (kyk Pirandello 1954). Henry $I V$ vertel die verhaal van 'n man wat twintig jaar vantevore van 'n perd afgeval het tydens 'n maskerade waarin die betrokke man die Duitse keiser Hendrik IV voorgestel of "gespeel" het. Die man was sedert die maskerade vir 'n lang tyd bewusteloos. In voorbereiding vir die maskerade het die man die biografie en styl van Hendrik IV grondig bestudeer, selfs sy mannerismes perfek leer 
naboots. Met die herwinning van sy bewussyn, was die man oortuig dat hy inderdaad Hendrik IV ís. Om hierdie geestestoestand te probeer akkommodeer, het die man se welaf suster hom in 'n Middeleeuse kasteel laat interneer, omring met akteurs wat almal soos Middeleeuse hoflui of courtiers aangetrek en opgetree het. So kon "Hendrik" sy waansinnige fantasieë bly uitleef, die waarheidsgehalte van sy bestaan oorbodig. Deel van die hoflui was twee pragtige dames, Donna Matilda en haar dogter Frida, asook 'n mediese dokter. Dit is juis ten opsigte van die erotiese soort verbintenis wat Hendrik met die vrouens probeer handhaaf, waar Pirandello die vraag telkens na vore bring of Hendrik werklik steeds waansinnig is, of bloot ter vervulling van allerlei heimlike begeertes, die rol van Hendrik bly speel. Pirandello laat Hendrik, soos die harlekyn in die Middeleeuse teater, telkens priemende vrae vra: Wie is jy werklik? Was jy altyd wie jy nou is? Was jy altyd dieselfde? Daarom weet ons nooit of Hendrik werklik 'n tragiese figuur is of bewus is daarvan dat hy 'n tragiese lewe lei nie. Indien hy wel 'n bewustelike tragiese figuur is, is hy nie waansinnig nie, maar ' $n$ manipuleerder. Indien hy nie 'n tragiese figuur is nie, is hy inderdaad hopeloos waansinnig. Hy is óf tragies, óf mal. Pirandello konfronteer Hendrik (en ons, sy lesers) egter met tragedie in die onmiskenbare, klassieke sin van die woord deur die mediese dokter daartoe te bring om Hendrik te "behandel" deur hom aan die werklikheid buite die kasteel voor te stel. Dit lei uiteindelik tot moord. Die maskerade het aanleiding gegee tot 'n spel, 'n vertoon, waarin wanvoorstelling en anargie bewustelik gehandhaaf is. Die uiteinde van hierdie spel is 'n saak van dodelike erns. Mense gaan dood hier ... Dit, sou Pirandello sê, is wat gebeur wanneer erns, orde en outentisiteit bewustelik verruil word vir die anargie van maskerades, waar die leuen en die waarheid mekaar oomblik vir oomblik bly vooronderstel. By 'n maskerade weet jy nooit wie speel wie nie. Jy mag dink dat jy seker is wie jý speel, maar jy kan nooit seker wees of iemand anders hom/haar ook speel en veral of iemand jóu speel nie. Sien jy kans om jouself by 'n maskerade te ontmoet? Sien jy kans om gespeel te word? Wie maskers wil dra, moet nie kla as die maskers afgetrek word nie. Hierdie probleemstelling van Pirandello geld nie net vir Al-Kaïda of die BushAdministrasie(s) nie. Dit geld ook vir Jean Baudrillard.

\section{MONNIKE, ORDES EN 'N NUWE SENSUS COMMUNIS}

Hoe rehabiliteer ons dan die erns van filosofiese waarheid? Sou ons nie dalk moes terugkeer na ouer waarhede, of ouer begrippe van waarheid wat as onproblematies "waar" in hulle tyd geag is nie? Is ons waarheidsprobleem nie, soos Gadamer in die fenomenale inleidingshoofstuk van Wahrheit und 
Methode (1979:19) gesê het, steeds ten diepste hermeneuties nie? Is dit nie dalk selfs logies-hermeneuties nie? Gadamer verwys onder meer (1979:19) na die Jesuït G Vico (1688-1744) se volgehoue aksent op sensus communis, wat ek pertinent kies om te verstaan as die opvatting van filosofiese kennis as 'n beskawingsbeginsel wat met ander gedeel kan word, of 'n beskawingsbeginsel wat onmiddellik kommunikeerbaar is of kan wees.

Maar vooraf ' $n$ ekskurs in die logika van my hantering van die begrip. Die opvatting van sensus communis erf ons uit 'n lang voorgeskiedenis wat ' $n$ hoogtepunt bereik het by die Engelse moraliste, wat sensus communis beskou het as common sense - en nie noodwendig as community sense, soos wat die protagoniste van ' $n$ volkome veelstemmige werklikheid dit vandag sou wou hê nie. In 'n oordeel oor gestel die skoonheid of die waarheid of die geregtigheid al dan nie van 'n saak, is sensus communis as common sense die beginsel van 'n redelike opvatting van skoonheid of waarheid of geregtigheid wat onmiddellik kommunikeerbaar kan wees. Daarmee word nie gesê dat 'n redelike opvatting van skoonheid of waarheid of geregtigheid altyd onmiddellik kommunikeerbaar moet wees nie. Dit hoef ook nie te beteken dat 'n redelike opvatting van skoonheid of waarheid of geregtigheid normaalweg of gangbaar onmiddellik kommunikeerbaar is nie. Wat sensus communis as common sense wel beteken, is dat daar 'n soort gebeure is of kan wees, wat so radikaal onverdund en onverbloemd in selfaanbod is, dat dit onmiskenbaar redelik, skoon, waar of geregtigheidsvol is - of dit onmiskenbaar nié is nie. Die soort gebeure is dus juis onkategories waar; dit word nie deur een of meer kategorieë bemiddel nie. Die soort gebeure oorval die subjek. Die soort gebeure is die betekenisvolle uitsondering in 'n werklikheid waarin die bemiddeling van dinge inderdaad gangbaar voorop staan. Soms, al is dit net heel soms, kan 'n mens oorval word deur die gebeure - oorkom word deur dit wat redelik, waar, goed of geregtigheidsvol is.

My logies-hermeneutiese standpunt is daarom die volgende: A) Die werklikheid is gangbaar bemiddeld. B) Daar is nietemin gebeure wat die subjek onbemiddeld kan oorkom (in Engels: overcome). C) Daarom kan die werklikheid nie beskryf word as volkome bemiddeld nie. Anders gesê: Die subjek ken die werklikheid in terme van veelvoudige kategorieë van bemiddeling. Dieselfde subjek word egter op sy of haar lewensweg oorkom deur gebeure wat onmiddellik herkenbaar is as redelik, waar, goed en geregtigheidsvol - of níe - hoe absoluut uitsonderlik dit ook al mag wees. Daarom moet die subjek in hierdie lewe rekening hou met meer as die kategorieë van bemiddeling.

Ek arriveer hierby op logiese gronde. Eers 'n illustrasie: Die uitspraak Alle uitsprake is vals kan slegs 'n sinnige uitspraak wees indien dit gemaak 
word vanuit 'n posisie buite of eerder jenseits die logiese struktuur van die uitspraak. Die uitspraak Alle uitsprake is vals vooronderstel dus 'n posisie waar dit moontlik geag word dat minstens een uitspraak nie vals is nie, naamlik die uitspraak dat alle uitsprake vals is. Die lot van die uitspraak Alle uitsprake is vals staan en val by hierdie logiese toegewing ${ }^{5}$. Die uitspraak Alles is bemiddeld kan eweneens slegs ' $n$ sinnige uitspraak wees indien dit gemaak word vanuit 'n posisie jenseits die logiese struktuur van die uitspraak. Die uitspraak Alles is bemiddeld kan nie met erns geneem word indien dit self 'n bemiddelde uitspraak is nie. Jy kan nie advokaat en regter in dieselfde saak wees nie. Jy kan nie pleit én beslis in dieselfde saak nie. Die uitspraak Alles is bemiddeld vooronderstel daarom 'n posisie - al is dit 'n uiters enigmatiese posisie - waarin dit moontlik sou wees om 'n onbemiddelde, herkenbare, verstaanbare, kommunikeerbare, deursigtige uitspraak te maak, naamlik dat alles bemiddeld is. Die lot van die uitspraak Alles is bemiddeld word dus gedetermineer deur die enigma van die onbemiddelde en nie die bemiddelde nie.

Hierdie taalfilosofiese konsekwensie - dat daar, hoe enigmaties ook al, 'n onbemiddelde werklikheid moet wees in ' $n$ werklikheid van gangbare bemiddeling - vind ons as rehabiliterende greep natuurlik nie in die moderne nie, maar in die voormoderne, daardie epog wat met soveel konsekwente vooroordeel as "donker" gekenmerk word. Ek is egter van mening dat die Carolingiese periode, vanaf $600-900 \mathrm{nC}$ (dit wil sê, die sogenaamde "donkerste tyd van die donker Middeleeue"), epistemologies 'n veel meer verligte tydvak was as wat die filosofie van die "Verligting" ooit kan/kon pretendeer om te wees. Die Carolingiese periode was die eerste periode van 'n rehabilitering van iets kosbaar wat vergete of verlore geraak het: Die skat van die klassieke, die logika van die taal Latyn en die logika van hulle wat Latyn gepraat het. Daaroor aanstons meer.

Ek verstaan sensus communis daarom as iets "Carolingies", in die sin dat dit 'n logika van die moontlikheid van onmiddellike geldigheid daarstel en ' $n$ fundamentele uitgangspunt ten opsigte van begrippe soos geregtigheid en skoonheid stel, wat lank voor Vico reeds diep en sonderling in die Jesuïtiese pedagogiek en voor dít in die Carolingiese lewensbeskouing, wat oor eeue heen in pertinent die Benediktynse kloosterwese bestendig is, gevestig was. Hierdie common sense opvatting van sensus communis is vandag skynbaar so 'n aanvegbare opvatting dat geen respektabele kontinentale intellektueel veral diegene wat meen dat iemand soos Baudrillard die waarheid en die waarheid alleen praat - vir 'n oomblik sou oorweeg om daarheen terug te keer

\footnotetext{
${ }^{5}$ Ek beskou hierdie toegewing uiteraard as epistemologies lotsbepalend vir die teologie, maar ook vir enige filosofie wat nog belangstel om erns te wil maak met die begrip erns.
} 
nie. Aangesien ek hier by implikasie afstand neem van die eietydse konsep van die intellektueel en my eerder intiem wil aannestel by die persona van die Carolingiese monnik, hinder dit my egter glad nie om hierdie rehabiliterende beweging te maak nie. Trouens, die gewilligheid om dit wat vergete of verlore geraak het met erns te bejeën, soos by Foucault, Blumenberg of Benjamin, is een van die aspekte van die "postmoderne voor Lyotard" wat ek altyd met entoesiasme sal onderskryf.

Terug by Vico: Wat Gadamer (1979:20ev) juis boeiend beklemtoon, is dat Vico buite die Cartesiaanse tradisie staan. Sensus communis was vir Vico nie gebaseer op 'n sekere matematiese, "rasionele" ideaal (soos by Hobbes se Leviathan of Descartes se Meditasies nie), maar dit was die basis waarop praktiese oorwegings onmiddellike gestalte kon kry en keuses gemaak kon word wat 'n hoë mate van sekerheid (verum certum) gebied het. Dit was 'n oordeel, onmiddellik en seker, wat gangbaar gedeel en verstaan kon word. Sensus communis ten opsigte van 11 September sou byvoorbeeld kon beteken dat elke mens wat met daardie of soortgelyke gebeure gekonfronteer sou word, onmiddellik en sonder huiwering, verum certum, die onreg daaraan sou afwys. Wat Vico, as professor in retoriek, egter ook nog by die verum certum voeg, is die humanisties-klassieke, retoriese ideaal van eu legein - om goed te praat en betekenisvol te praat. Eu legein het altyd hierdie twee betekenisse gehad: Enersyds om die goeie dinge te sê, dit wil sê altyd die waarheid te praat; en andersyds, om die goeie dinge goed te sê, om betekenisvol die waarheid te praat. Binne die konteks van my monnikagtige opvatting van sensus communis sou eu legein kon beteken dat daar sekere sake is waaroor 'n mens, onmiddellik en seker, betekenisvol die waarheid kon praat. Natuurlik is hierdie opvatting deur die latere moderne projek self verguis, sou hierdie soort waarheid aan sensus communis naïef, selfs primitief wees, 'n terugkeer na die tyd voor die mondigwording van die mens toe alle sekerhede metodies verdaag is. My vraag na 11 September is wat oorbly as die mondigwording self besig is om te faal en die moderne projek self besig is om in die ekstreme konsekwensies daarvan (want dit is die postmoderniteit van Baudrillard wél), katastrofies ten einde te snel. Is al wat oorbly dan nie 'n heroordenking van die ou wêreld, waar minstens sommige dinge nog verum certum was nie?

Gadamer verwys in sy ekskurs (1979:25ev) baie kortliks ook na die skolasties-Aristoteliese agtergrond van sensus communis. Die Aristoteliesskolastiese tradisie rig sigself polemies teen die metafisika en die oplossing daarvan in skeptisisme, en stel 'n benadering voor van outentieke oordeel, der gesunde Menschenverstand, le bon sens, sensus communis. Die Aristoteliesskolastiese tradisie se bydrae tot die ontwikkeling van die begrip sensus 
communis (dus, grootliks voor Vico) kan volgens Gadamer moeilik oorskat word: Enersyds vanweë (1a) hierdie tradisie se kenmerkende klem op die sintuie se vermoë om kennis te voorsien, dat die sintuie vertrou kan word, om (1b) daarmee die eksesse van die destydse spekulatiewe filosofie te temper; andersyds (2) die beklemtoning van die diepgaande verbintenis tussen sensus communis en die sosiale lewe. Van hierdie verbintenis sê Gadamer (1979:25): "[Die] filosofie van gesonde verstand was nie net 'n remedie vir die 'maansiekheid' van die destydse metafisika nie, maar het ook 'n basis voorsien vir 'n morele filosofie wat die opvatting van geregtigheid in die gemeenskapslewe gestand gedoen het".

Ek is, na die myns insiens teenspraakvrye argumente van onder andere Arthur Hyman en James Walsh (1973) daarvan oortuig dat die opvatting van sensus communis na die klassieke era via Alcuin reeds weer in die Westerse kloosterwese van die sewende en agtste eeue hervestig was en nie eers later, sedert die Renaissance, sistematies na die skolastiek teruggevoer is nie. Van die heel vroegste kloosterwese as sodanig sou gesê kon word dat dit radikaal private, teruggetrokke ruimtes was waar minimalisme en meditasie as kodes vir ' $n$ behoorlike lewensvoering gestel was. Na die aanvanklike grondslag wat vir hierdie minimalistiese, meditatiewe lewensvoering gestel is deur die lewe en werk van Martin van Turyn, die eerste en outentieke Westerse monnik wat dood is in 397nC, was dit Augustinus van Hippo wat die kloosterwese as sodanig aanvanklik georganiseer het. Selibate kerkmense het hulle volgens hierdie organisasie in 'n identifiseerbare, plaaslike ruimte teruggetrek en die plaaslike kerk en ook die wyer gemeenskap gedien. In 388nC organiseer Augustinus 'n klooster in Noord-Afrika, wat ook na sy aanwysing as biskop van Hippo, bly voortbestaan het. Hier is die grondslag gelê vir die kloosterwese in die betreklik gelykblywende vorm daarvan oor die volgende duisend jaar heen in Europa, Brittanje en lerland: Hierdie vorm behels naamlik 'n sober, private, selfs radikaal teruggetrokke ruimte, die teenwoordigheid van 'n biskop of ab, omring deur gesubordineerde monnike en jong studente wat voorberei is vir ordening, wat 'n lewe volkome in diens van die waarheid tot die eer van God wou lei. Die klooster was eenkant maar tog ook fundamenteel deel van die gemeenskapslewe; teruggetrokke, maar nie onttrokke nie. Monnike, vanaf die heel vroeë Benediktyne tot die latere Cistersiane, die uiters aksetiese Carthusiane en veel latere Dominikane en Fransciskane, het sentraal gestaan in sowel die intense teologiese debatvoering van hulle tye as ' $n$ betrokkenheid by die gemeenskap waarin hulle, hoewel ruimtelik eenkant, geleef het.

Ek wil uiteraard nie voorgee dat die kloosterwese so gelykblywend was dat daar geen veranderinge van die $6^{\mathrm{e}}$ tot die $15^{\mathrm{e}}$ eeue plaasgevind het nie. 


\section{Terreur, roes en ordes}

Die ordes het in vorm en selfaanbod onderling van mekaar verskil. Die vurige en trotse Carolingiese Benediktyne van die $6^{\mathrm{e}}$ tot die $9^{\mathrm{e}}$ eeue het byvoorbeeld min in gemeen gehad met die Fransciskaanse bedelordes van die 13 eeu of die meer nomadiese lerse ordes, terwyl daar natuurlik ook dramatiese teologiese verskille tussen die ordes en selfs binne die ordes voorgekom het. Persoonlik verleen ek voorkeur aan die profiel van die Benediktynse monnik van die $7^{\mathrm{e}}$ tot die $9^{\mathrm{e}}$ eeue, 'n orde wat vir 700 jaar werklik gelykblywend was en ook daarna min verander het. Die Benediktyne was volgens hierdie bedrewe navorsers van die vroeg-Middeleeuse filosofie, Hyman en Walsh (1973), in leer en in lewe die eerste Middeleeuse herbestendigers van die klassieke epistemologiese opvatting van sensus communis: Hierdie wêreld is sakramenteel, maar nie altyd nie.

Die persepsie van die middeleeuse monnik as 'n steriele, goedige en dikwels blasé togadraer is myns insiens ver van die merk af, gemeet aan veral die sober, maar veral selfgeldende profiel van die vroeë Benediktyn. Die lewe in die vroeë Benediktynse kloosters was, om die minste te sê, indrukwekkend: Spartaans, selfs ook in militêre sin. Trouens, die hiërargie in sommige kloosters was 'n presiese replika van 'n Romeinse centurion. Onder leiding van vroeë sentrale figure soos Johannes Cassianus in die suide van Frankryk en Cassiodorus in die suide van Italie, is hierdie kloosters as selfonderhoudende en selfadministrerende institusies ingerig, waar meditasie, gebed, onderhoudswerk, studie, min slaap en nog minder voedsel asook harde fisiese inspanning die monnik se hele lewe in beslag geneem het. Die Benediktynse lewe was meedoënloos streng en toegewyd. Met hulle swart mantels en indrukwekkende intellektuele en fisiese vermoëns, word daar van die Benediktyne gesê dat hulle die mees edele draers was van 'n sobere, aristokratiese lewenshouding voor God. 'n Benediktynse monnik in die Carolingiese tyd was inderdaad ' $n$ vreeslose en intimiderende opponent. Daar word van vegtermonnike vanuit sekere Benediktynse sub-ordes en die latere Riddermonnike van St Johannes en die Ridders van Templar wat uit hulle voortgekom het, gesê dat hulle tel onder die dapperste van alle soldate in die Westerse krygsgeskiedenis. Hulle sou hulle lewe nie net aflê vir hulle orde nie, maar vir orde as sodanig. Vir veritas sou hulle sterf.

$\mathrm{Na}$ Cassanius en Cassadorius was figure soos die formidabele filosoof en kloosterorganiseerder Alcuin, maar ook die vroeëre Boethius en Gregorius die draers van 'n uiteindelik meer as 'n duisend jaar oue intellektuele hartstog waarvan navorsing en doseerwerk, sekere vroeë vertalings van klassieke tekste, die keurigste kopiërings van klassieke en eietydse tekste, die byeenbring en redigering van klassieke filosofiese tekste in Grieks en Latyn en veral die bewaring van tekste en intellektuele tradisies midde ontsettende 
politieke en staatkundige onrus deur Wes- en Suid-Europa, Brittanje en lerland heen, die vrug was. Kenmerkend van die monnike se intellektuele arbeid was die presisie, die deeglikheid en integriteit wat dit gekenmerk het; die vermoë én gewilligheid om te analiseer en die vergange met erns te bejeën. Die monnik, van welke orde ook al, was 'n formidabele bewaarder van wat dit ook al was wat aan hom toevertrou is. 'n Mens hoef maar net hoofstukke 5 en 11-19 van F C Copleston se magistrale A History of Medieval Philosophy weer 'n keer te lees, om onder die indruk te kom van die rol wat die monnikewese gespeel het in die bewaring en bestendiging van begrippe soos "waarheid", "deug", "orde" en "tradisie". Nie sonder rede nie, is daar na die bestendigende monikkeskole as "ordes" verwys.

Copleston se gestandaardiseerde inleidingswerk tot die Middeleeuse filosofie stel 'n mens nie net bekend aan die persoonlikhede en omvattende, trouens verbysterende, intellektuele arbeid en produktiwiteit van monnike soos Cassianus, Cassiodorus, Boethius, Gregorius, Benedictus van Nursia, Bonifacius, Alcuin, en later Anselmus, Abelardus, Bonaventura, Albertus, Thomas Aquino, Duns Scotus, Willem van Ockham, Marsilius van Padua en Nikolas van Cusa nie, maar aan die enorme bydrae wat hulle en hulle medegangers gelewer het ter bewaring van die orde, telkens wanneer ordes voor afgronde gehuiwer het. Sonder om nou tematies daarop in te gaan, nooi ek $u$ uit om Copleston se gevierde teks weer ter hand te neem, of meer onlangse en selfs meer uitgebreide versamelwerke, soos die vermelde Philosophy in the Middle Ages (1973) van Hyman \& Walsh of Paul Dutton se fantastiese boek Carolingean Civilization (1993), te oorweeg. Die Westerse geskiedenis is volgens hierdie navorsers sonder die monikketeenwoordigheid, met hulle eiesoortige klem op sensus communis, geheel en al onvoorstelbaar. Dit is trouens die mees sentrale aspek van die ontwikkeling van die Westerse geestesgeskiedenis sedert die val van Rome. Daar sou geen sprake wees van die skepping, bewaring en ontwikkeling van 'n Westerse samelewingsorde as dit nie vir die kloosterwese was nie. Sedert Boethius in die sesde eeu Aristoteles se De Interpretatione en Categoriae met kommentaar aan die vroeë Benediktyne beskikbaar gestel het, het die opvatting van sensus communis geresoneer met die wese van Benedictus van Nursia se 73 Benediktynse reëls: Herken die waarheid, verdedig die waarheid en leef die waarheid uit in gemeenskap met ander.

Waarom vind ek hierdie vroeë monikkegeskiedenis so aantreklik en opnuut aktueel? Ek kan moedswillig wees en sê dat spesifiek die Benediktynse monnik vanuit die sentrale Carolingiese periode, die $8 e$ tot die $9 \mathrm{e}$ eeue, en die hartstogtelike vegterordes, die ridders van verum certum, wat uit hulle na vore gekom het, vir my na 11 September alles is wat Baudrillard 
nié is nie. My aktualisering is gerig op die erns van die monnik, sy toegewydheid, sy soberheid, sy verknogtheid aan eu legein en sensus communis. Hoe meer ek oor die Carolingiese samelewing nalees, hoe meer raak ek daarvan oortuig dat minstens sommige van die antwoorde op die baie vrae wat ons na 11 September behoort te hê oor waarheid, skoonheid en geregtigheid, êrens tussen die $6^{\mathrm{e}}$ en $9^{\mathrm{e}}$ eeue gesoek kan word - en gewis nie meer met soveel bevooroordeelde fokus op 1641 met die publikasie van Descartes se Meditasies nie.

Ek is heeltemal bewus van die aanvegbaarheid van my aktualisering. Natuurlik is ek hier besig met ' $n$ positiewe soort kontinuïteitsopvatting. Natuurlik is hier sprake van 'n nuwe individualiserende mite, selfs die herhaling van 'n ouer beeld, dalk, sou Baudrillard sê? Dalk spreek die beeld van die monnik van 'n nuwe versugting na 'n verenigde, gebonde, gesentreerde Self, as sodanig ' $n$ terugval in die hoë moderne? Natuurlik verraai my interpretasie van sensus communis ' $n$ vertroue in dieptestrukture (in betekenis, waarde, inhoud, in die verwysde) bo die Baudrilliaanse oppervlaktestrukture van verskyningsvorme, uitwendige vorme en die selfineenstortende verwyser. Natuurlik ontken sensus communis die geldigheid van Baudrillard se hiperrealiteit, sy opvatting dat niks ervaar kan word as objektief of onbemiddeld nie. Natuurlik dink ek hier, minstens op sigwaarde af, histories lineêr. Natuurlik neem ek die metaverhale van oorlewering en die outoriteit van die tradisie hier weer met erns.

Tog is hier eerder sprake van 'n fusie van tradisies, die heel oue en die heel onlangse, as bloot 'n moedelose terugval in die pre-moderne. Want waarop anders moet 'n mens jou beroep as juis die kritiek van die vergange besig is om die 21 eeuse mensheid te faal? Wat anders as die heroorweging van die vergange in 'n fusie van tradisies bly dan oor? Wat anders as die verwaarloosde en vergete momente uit die geskiedenis het 'n mens wanneer Baudrillard ' $n$ mens met net die herhaling van beelde en die sublimering van die brutale laat? Hoe anders moet 'n mens dan praat oor geregtigheid, sodat ander jou verstaan en dit onmiddellik met jou eens kan wees of van jou kan verskil? Wat anders as ' $n$ hernieude en innige gesprek met die tradisie het ons na 11 September, die dag waarop dit duidelik geword het dat ons voortdurend te min sal hê om die tradisie finaal agter te laat?

Ek sou dus verkies dat my eerbied vir die erns en toewyding van die persona van die monnik ten aansien van waarheid, orde en geregtigheid nie gesien moet word as 'n lineêre terugval in Middeleeuse denkpatrone nie, maar as 'n krities-sikliese beweging, as inderdaad ' $n$ "eerste-beginsel" versugting om dit wat wesenlik tot die filosofie vir ruim 800 jaar was, positief te rehabiliteer in 'n eietydse konteks waar filosofiese praxis toenemend min erg 
het aan juis eerste beginsels of die wese van dinge; 'n konteks waar slegs nog die afskynsel wesenlik is.

Uiteraard sou ek nie hiermee wou sê dat die "postmoderne", wat hierdie ongenuanseerde begrip vandag ook al alles behels, met allerlei reaksionêre sanksies belas moet word nie. Ek sou wel wou pleit vir' 'n vorm van intervensie; ek sou wel wou sê dat die roeserige verwaandheid van die jongste weergawes van "postmoderniteit" onderbreek moet word deur'n nuwe innigheid, 'n nuwe versugting na soberheid en erns in die filosofie. Nothing beats common sense on a cold day, sou Bertrand Russell sê. En hierdie onderbreking vra afstandname, teruggetrokkenheid, selfs negasie, Adorno en Hezel se bestimmte Negation.

Ek aanvaar dat hierdie argument, of 'n soortgelyke rehabiliterende argument, deur baie vandag as tragies geag sou kon word. Ek vra egter juis met inbegrip van die tragiese die vraag na die deugde wat in terugtrekking opgesluit mag lê. Ek vra my na die persona van die monnik af of daar nie 'n onbedinkte deugdelikheid in terugtrekking vestig nie, ook al beteken dit dat 'n mens stil moet word en nie langer sal "verskyn" nie. Wanneer ek Baudrillard en Augustinus langs mekaar probeer lees, wonder ek juis of dit nie tyd geword het vir stilte nie. Ek wonder of dit nie tyd geword het om huis toe te gaan en die primêre tekste van die Westerse beskawing behoorlik te lees, in Latyn, met behoorlike filologiese aantekeninge, voorsien van keurige grammatikale analises, voordat die waarheid a lá Baudrillard so onwaaragtig gestel word nie. Ek wonder of dit nie tyd geword het vir 'n nuwe deeglikheid ten aansien van en 'n grootse eerbied vir skoonheid en geregtigheid nie - al is daardie eerbied uiteindelik selfkoesterend.

Die monnikefiguur was tog juis die draer van sensus communis in 'n tyd toe waarheid en geregtigheid sleutelbegrippe vir 'n behoorlike en inderdaad selfkoesterende lewensvoering was. Daarom het monnike min gepraat en soms vir maande aaneen glad nie gepraat nie. 'n Monnik het net gepraat wanneer dit eu legein kon wees. Om te skinder of met los praatjies en innuendo in 'n klooster besig te wees, was 'n groter taboe as enige seksuele taboe. Monnike was stil, teruggetrokke en studerend. Daar was te veel respek vir die waarheid om enigiets anders te wou wees. Dit maak die monnik vir my, vandag meer as ooit tevore, 'n blywende simbool van die soort erns ten aansien van waarheid en geregtigheid waartoe die filosofie eens in staat was. Ek wil terug daarheen.

Die monnik is 'n teken van die "goeie orde", om Baudrillard se eie woord te gebruik. Anders as die teken van die "kwaadwilige orde", wat die werklikheid intensioneel wanvoorstel, of die simulacrum, die teken van die "orde van towery", waar die betekende in die teken self na benede stort, is die 
monnik ' $n$ teken van suiwerheid en soberheid, selfs dapperheid, van epistemologiese naïwiteit, van 'n kennislerige onskuld ten aansien van die waarheid. Die monnik is ook aantreklik omdat hy in terme van die geleefde lewe so 'n dialektiese figuur was - enersyds deel van die gemeenskap waarvan die klooster sélf deel uitgemaak het; andersyds, terselfdertyd, teruggetrokke en afstandelik; selfonderbrekend, terugtredend en gereserveerd; enersyds asketies in gebed en studie; andersyds publiek militant wanneer omstandighede dit genoodsaak het. Die monnik was nie 'n burger van die praterige, sardoniese, speelse ryk van Jean Baudrillard nie.

Die monnik was 'n figuur wat vir minstens 800 jaar radikale erns en soberheid in waarheidsleer verteenwoordig het. Sedert 11 September 2001 het ek 'n versugting na sy erns en soberheid. Want op 11 September is ons beskaafde gasvrou se foyer verniel en haar kristalglase gebreek. Dit getuig ingelyks van beskaafdheid om op hierdie punt verskoning by haar te maak en terug te keer huis toe.

\section{Literatuurverwysings}

Adorno, Th W 1971. Zur Metakritik der Erkenntnistheorie. Gesammelte Schriften

5:9-245. Frankfurt am Main: Suhrkamp.

Baudrillard, J 1995a. The Gulf war did not take place, tr by C Turner. Bloomington, IN: Indiana University Press.

Baudrillard, J 1995b. Simulacra and simulation, tr by S Glaser. Ann Arbor: University of Michigan Press.

Baudrillard, J 2003. The spirit of terrorism, tr by C Turner. London: Verso.

Bernauer, J \& Carrette, J (eds) 2004. Michel Foucault and theology: The politics of religious experience. Hampshire: Ashgate.

Beukes, J 2002. Vanaf laat-strukturalisme na post-strukturalisme: 'n

Kontekstualisering van Jean-François Lyotard se Discours, figure. HTS 58 , 994-1010.

Borradori, G 2003. Philosophy in a time of terror: Dialogues with Jurgen Habermas and Jacques Derrida. Chicago, IL: University of Chicago Press.

Dutton, P E (ed.) 1993. Carolingean Civilization: A reader. Peterborough: Broadview.

Frank, M 1988. Die Grenzen der Verständigung: ein Geistergespräch zwischen Lyotard und Habermas. Frankfurt: Suhrkamp.

Gadamer, H-G 1979. Truth and method. London: Sheed and Ward.

Habermas, J 1987. The philosophical discourse of modernity: Twelve lectures Massachusetts, MA: MIT.

Hyman, A \& Walsh, J J 1973. Philosophy in the middle ages. Indianapolis, IN: Hackett.

Jameson, F 1992. Postmodernism, or, the cultural logic of late capitalism. Durham, NC: Duke University Press. (Post-Contemporary Interventions Series.) Jameson, F 2002. A singular modernity: Essay on the ontology of the present. London: Verso. 
Kilian, M 1998. Modern and postmodern strategies: Gaming and the question of morality: Adorno, Rorty, Lyotard and Enzensberger. New York: Lang. (Studies in Literary Criticism and Theory 11.)

Leezenberg, M 2004. Power and political spirituality: Michel Foucault on the Islamic revolution in Iran, in Bernauer, J \& Carrette, J (eds), Michel Foucault and theology: The politics of religious experience, 99-115. Hampshire: Ashgate

Lyotard, J-F 1984 (1979). The postmodern condition, tr by G Bennington, \& B Massumi. Oxford: Manchester University.

Lyotard, J-F 1991 (1989). The inhuman: Reflections on time. Cambridge: Polity.

Norris, C 1997. Deconstruction: Theory and practice. New York: Routledge.

Norris, C 1993. The truth about postmodernism. Oxford: Blackwell.

Norris, C 1998. What's wrong with postmodernism: Critical theory and the ends of philosophy. Baltimore: John Hopkins University Press.

Pirandello, L 1954. Six characters in search of an author. London: Heinemann.

Sim, S 2000. Lyotard and the inhuman: Postmodern encounters. Cambridge: Icon.

Virilio, P 2002. Ground zero, tr by C Turner. London: Verso.

Zizek, S 2002. Welcome to the desert of the real: Five essays on September 11 and related dates. London: Verso. 